\title{
DRAWING SPANIARDS IN THE PHILIPPINES \\ Displacement, Brutalization, and the Dissident Eye of Ignacio del Villar
}

\author{
Rocío Ortuño Casanova \\ Universiteit Antwerpen \\ rocio.ortuno@uantwerpen.be
}

\begin{abstract}
This article explores the Spanish colonization of the Philippines and their colonial culture and society as portrayed in the comic strips by Ignacio del Villar, a Spanish cartoonist who drew for Philippine colonial magazines in Spanish. His pictures, whose principal audience was the Spanish-speaking community of Manila in the late nineteenth and early twentieth centuries, satirize the alienation of the Western individual in the Philippines. His mockery of the generalized colonial attitude of "monarch of all I survey" links del Villar with dissident colonial accounts, as discussed by Mary Louise Pratt in Imperial Eyes. This article inquires on the reasons why del Villar seemingly veered away from traditional colonial discourses, resulting in the mockery of the self-image of social superiority that Spanish residents in the Philippines strived to maintain in a complex society where class and origin were difficult notions to define.
\end{abstract}

\section{Keywords}

Bhabha; colonial representation; Fil-Hispanic culture; Philippine cartoons; Spanish cartoonists; Spanish colonization of the Philippines

\section{About the Author}

Rocío Ortuño Casanova holds a PhD in Hispanic Studies from the University of Manchester (UK). She has taught in British universities for five years before moving to the Philippines to teach at University of the Philippines - Diliman for three years. She has specialized in Philippine Literature in Spanish and is the scientific director of the portal on this topic in the Virtual Library Miguel de Cervantes. She currently works at the Department of Literatures of the University of Antwerp (Belgium) from where she leads a project of cooperation with the University of the Philippines to digitize rare Filipino periodicals. She has published about 
Filipino-Spanish cultural relations in journals such as Bulletin of Hispanic Studies, Neophilologus, Iberoromania, and Revista de Literatura. She has also published on Spanish song-writing and Spanish twentieth-century poetry. On this topic, she published in 2014 a book on Christian myths in the Spanish Generation of 1927.

Kritika Kultura 33/34 (2019/2020): 6-035

(c) Ateneo de Manila University

<http://journals.ateneo.edu/ojs/kk/> 
In 1891, the popular Spanish-born cartoonist Ignacio del Villar published a twopage cartoon called "Filipinas (según unos)" (The Philippines [According to Some]; see Figure 1) in the Philippine satirical magazine Manililla. The cartoon was divided into six scenes. It scoffed at Spanish colonial subjects in the Philippines and aimed to de-idealize a constructed image of both the nature and the role of the colonizers in the country. Moreover, the scenes pretended to represent peninsular Spaniard views on the Philippines. The subtitle, "According to Some," however shows a distancing of the artist from the constructions of social distinction consolidated around the controversial notion of "calidad" [quality] during those last years of Spanish colonial rule in the Philippines. This article will discuss a series of cartoons drawn by Ignacio del Villar and will target mainly the obsession with appearances among the Spanish and mestizo communities in the Philippines, which was caused by the anxious need to demonstrate a status of "calidad" not always self-evident in the complex Manileño society.

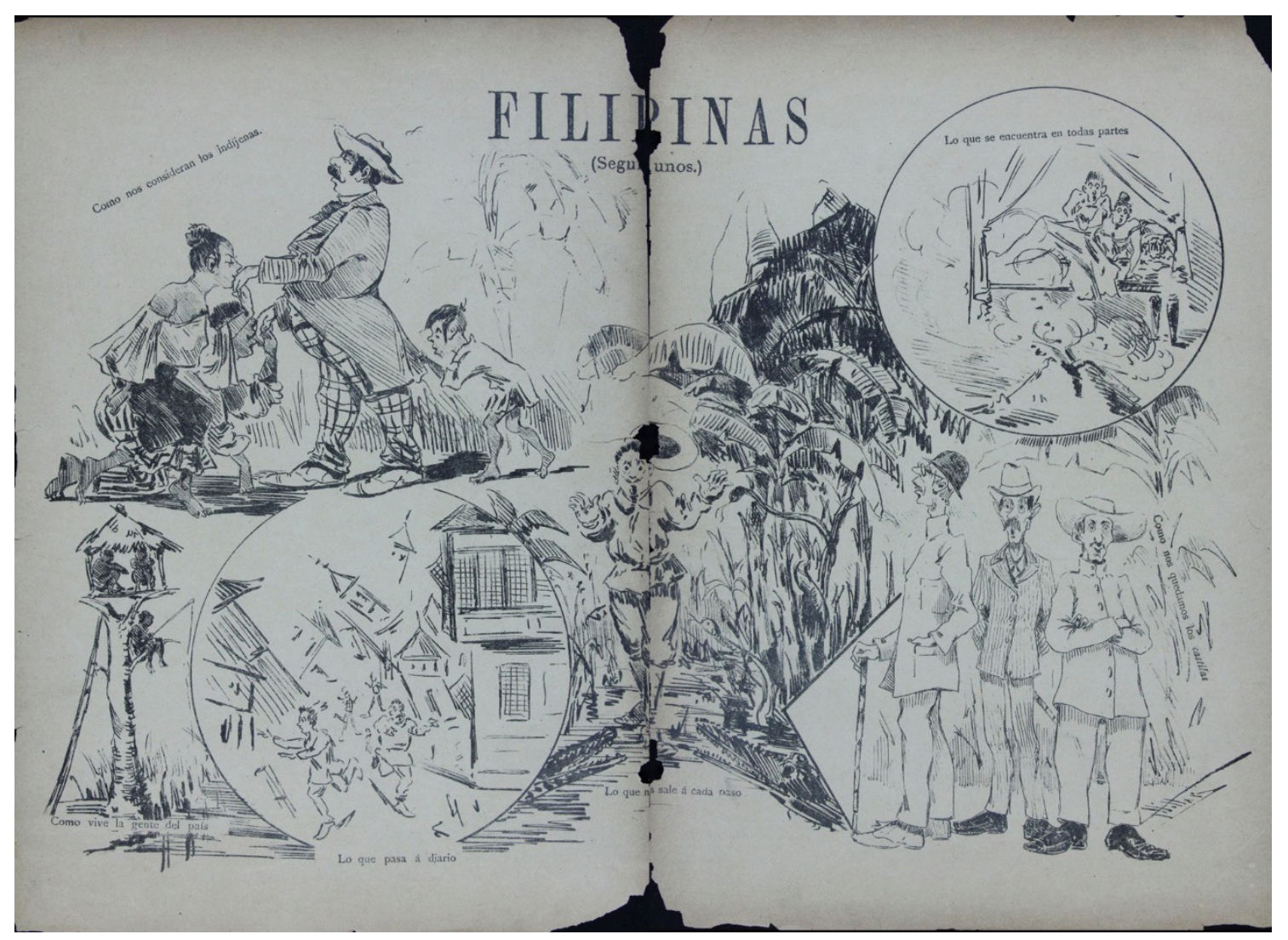

Fig. 1. "Filipinas (según unos.)" Manililla, number 145, 31 January 1891. Ateneo de Manila University. 
Written on the lower right corner of the image above is a sentence in the firstperson plural, "Cómo nos quedamos los Kastilas" [How we, the Spaniards, react]. Kastila is a term used by Filipinos to refer to any Spanish person born in the Iberian Peninsula (Thomas 2187). The illustrator's use of the first-person plural indicates that the author is including himself in the group represented by the three white men wearing hats, button-up jackets, and moustaches. Their eyes and mouths are wide open and they are observing everything with surprise. On the upper right corner frame, a scene portraying three Indian people kissing a white man's shoes is titled "Cómo nos consideran los indígenas" [How indigenous people consider us]. This perception is, of course, intimately linked to the expectation of the colonizer that the subaltern takes a submissive role toward the invader. Indeed, this was the attitude that Vicente Barrantes Moreno had in his Apuntes interesantes sobre las Islas filipinas. He said that Filipinos were submissive and were fond of Spaniards, as affirmed by Torres-Pou (126). Despite not having visited the Philippines, Adolfo de Mentaberry wrote in his book Impresiones de un viaje a la China similar impressions on the Filipinos, who apparently saw the Spanish authority as a god and the kastila as their prophets (Torres-Pou 187). Although this must have been a generalized idea among peninsular Spaniards, the cartoon is intentionally exaggerated in its portrayal of indios kissing the hands and the hem of the jacket of a kastila. This hyperbolic depiction evidences a self-ironic persona that questions the colonial point of view. When standing alone, the Indian is portrayed as the good savage: the scene on the lower left corner represents "Cómo vive la gente del país" [How autochthonous people live], and shows short, dark-skinned people in treehouses, fishing in the rivers, naked, and living a peaceful life. If this depiction seems to match the trope of naturalization developed by David Spurr regarding colonial discourse (56), the comical side appears when we contrast the bucolic scene with the continuous fright and awe experienced by the Spaniards represented in these texts.

The source of such fright and awe is also another element of otherness, and it is embodied by the environment in three of the illustration's frames: the central frame, titled "Lo que nos sale a cada paso" [What comes up at every step], the one on the left, "Lo que pasa a diario" [What happens everyday], and the one on the upper right, "Lo que se encuentra en todas partes" [What can be found everywhere]. In all three of these frames, white people (presumably kastila) as del Villar is again using the first person plural, are running away in despair from "violence" of a natural cause: an earthquake, a volcanic eruption, and the jungle itself. The picture of the volcano also includes the picture of an adulterous couple, which produces a double meaning: the heat, steaming, and violence of the volcano is applied also to sexual intercourse. Moreover, the epigraph does support this double meaning, as by talking about the ubiquity of a phenomenon, it could be interpreted as referring to either volcanoes or sex scenes. Volcanic eruptions were indeed recurrent in a 
country with 49 active and potentially-active volcanoes: Mount Mayon had long eruptions between 1881 and 1882, Makaturing in 1882, Musuan in 1867, Bulusan in 1886 and 1889 , among others. ${ }^{1}$

The wild and dangerous environment seems to justify the kastila's alienation. We find in del Villar's discourse, therefore, a subversion of the trope "monarch of all I survey." As M. Louise Pratt describes, this trope has three main features: 1 ) in its rhetoric, the landscape is estheticized and characterized as existing in a state of balance; 2) a density of meaning is sought with the use of a high number of adjective modifiers; and, 3) there is a relation of mastery between the seer and the seen (200). Del Villar mocks each one of these features of the usual imperial discourse. Instead of portraying a stylized landscape that transmits esthetic pleasure, nature becomes an enemy, impossible to "control." Moreover, the relation of mastery between the seer and the seen is mocked in "Cómo nos consideran los indígenas" [How Indians consider us]. The reverence that Filipinos are showing in the picture is contrary to real events such as the insurrection acts that occurred in 1872, and to testimonies of other Spaniards who would talk about natives as "incontrolables" [uncontrollable] (Feced 104-106). Although the use of adjectives and modifiers cannot be so important in a cartoon, there is another kind of multiplicity of significance: that of double meaning and irony as seen in the images.

Pratt would approach a similar case of mockery of the mainstream colonial discourse and call it "rhetoric of illegitimate presence" in her catalogue of colonial writings (205). She labels Mary Kingsley's Travels in West Africa (1897) with that name, but her dissident view is marked primarily by her gender. This is because, according to Pratt, "[it] is hard to think of a trope more decisively gendered than the monarch-of-all-I-survey scene” (209). In Kingsley's parody, as well as in del Villar's, mockery is directed towards man's power. His satirical portrayal evidences a detachment from contemporary written testimonies in chronicles and travelogues. Besides the abovementioned books written by Mentaberry and Barrantes (TorresPou 187), there seems to be a boom in the publication of journals, history books, reports, and impressions on the Philippines since the creation of the "Consejo de las Filipinas y de las posesiones del Golfo de Guinea" [Council for the Philippines and for the Spanish territories in the Gulf of Guinea] between 1870 and 1898. Only in the Biblioteca Virtual Miguel de Cervantes, there are 18 of those testimonies compiled. As opposed to the British colonial accounts that Mary Kingsley mocked, these publications do not stress the goodness of the territory, but rather constitute a discourse of failure and a string of complaints against the attitude of the native Filipinos. They often portray indios as incompetent and the Spaniards as patient teachers exasperated by the indolence of the natives. Pablo Feced concludes in his book that Spaniards were "compatriotas que luchan á brazo partido, en combate interminable y diario, con ineptitudes y apatías" [compatriots who fight fiercely, 
daily, constantly, against ineptitude and apathy] (350). Meanwhile, Francisco Vila wonders in 1880 about the cultural quality and work capacity of Filipinos:

¿Y sus artes? ¿Y sus ciencias? ¿Y su industria? ¿Y su riqueza?

Pena, cuando no risa, causa el ver los procedimientos, los instrumentos, los medios de que se valen para sus artes, oficios y profesiones. Trabajos en Europa facilísimos e insignificantes, son allí difíciles, largos y costosos. El buen gusto allí es cosa desconocida; las ridiculeces y extravagancias, moneda usual y corriente.

[What about their arts? And their sciences? What about their industry? What about their richness? Seeing their procedures, their instruments, the means that they use for performing their arts, their jobs, their professions provoke pity if not laughter. Works that in Europe would be extremely easy and insignificant are difficult, and consume time and money there. Good taste is unknown there. Things are usually ridiculous and extravagant.] (11)

Therefore, del Villar does not mock the portrayal of nature in Spanish texts; on the contrary, his cartoons agree with Spanish texts that describe Philippine nature as dangerous and unsuitable, and diverges from texts that otherwise idealize it. Furthermore, the discourse of "monarch of all I survey" in the Spanish texts on the Philippines focuses on the mastery of the seer over the seen alone. A good example of this is the tale "El vago y el matandá" [The Newcomer and the Oldtimer], published in Cuentos filipinos by José Montero y Vidal (1883). In this story, a Spanish public worker goes to Manila and meets other Spaniards who have been living there for a long time. Those old-timers are completely integrated into the community, except for the challenges of the autochthonous nature. For example, they never get used to the earthquakes, and warn the newbie Spaniard in Manila against sunshine, storms, and bananas. The tale is both a guide to good habits in the Philippines and a catalogue of traditions and curiosities of natives in the country, including celebrations (104-106), as well as the usual complaints found in texts written by Spaniards at the time: the passivity of the Indians, their dishonesty, and their laziness (110-111). Its description of the habits in the country matches the eagerness for classification and cataloguing of possessions found by Pratt as part of the "monarch of all I survey" discourse. Indeed, we find multiple examples of texts showing condescendence and irritation toward Filipinos, contrasting them with the natural quality ("calidad") found in the Spanish character (Borrero; González Serrano; Fray Gaspar de San Agustin in Fulgosio 32-37). In del Villar's cartoons, "calidad" is a social-ethnical notion with moral implications that is questioned. This will be the target of his mockery and the emblem of his divergent view or "not-soimperial eyes." 
However, as opposed to the parody of the "monarch of all I survey" discourse implemented by Kingsley in Travels in West Africa, gender is not the trigger that leads del Villar to his dissident drawings. Therefore, the next pages will explore how his view becomes dissident, that is, what makes del Villar so uncomfortable in the role that he is meant to have as a white colonizer in the Philippines. His perspective will bring into the surface a privileged point of view that will question Spanish traditional categorizations and discourses on the Philippines in the context of the decline of Spanish power.

To address these questions, this article, first, will introduce a history of satire in the Philippines. Second, it will discuss the circumstances of Ignacio del Villar that place him in an in-between place and provide him with a peripheral view of the situation. Third, this article will describe Philippine society at the end of the nineteenth century and contrast it with Philippine society as depicted in some of del Villar's drawings.

\section{WEEKLY SATIRICAL MAGAZINES IN THE PHILIPPINES}

According to Jesús Valenzuela, Wenceslao Emilio Retana, and Manuel Artigas Cuerva, the first satirical weekly magazine published in the Philippines was $L a$ semana elegante, which came out on 1 March 1884 (Valenzuela 54; Retana 260; Artigas Cuerva 159). La semana elegante would be the first of many in HispanoFilipino journalism which, according to Valenzuela, distinguished itself through its particular propensity for publishing satires of "the officials and other personages in Philippine history ... the merits or demerits of persons, things or institutions they wished to lampoon" (54). Satire in those colonial satirical weeklies was, however, not so sharp as the trend initiated in Spain in 1868. In 1868, the Revolución Gloriosa, a law pertaining to press freedom was approved in the Spanish government and confirmed in the Constitution of 1869 . Both this recent freedom and an improvement in the printing press led to an outburst of newspapers. About 600 newspapers were being printed in Spain in the second half of the nineteenth century (García Castañeda 3). During the Bourbon Restoration (1874-1923), parliamentary liberties were maintained. However, the social discontent toward the corrupt government increased the popularity of the satirical press (Marimon Riutort 150). Moreover, the cartoons became a result of the improvement of printing techniques (Guilarranz Ibáñez). After the opening of the Suez Canal in 1869, communication with Spain became more fluid, and therefore both professional cartoonists and journalists arrived in the Philippines, although they did not enjoy in the Asian colonies the same liberty as in Spain. Certainly, a taste for satire had also begun to develop there, but in 1856 the Permanent Commission of Censorship had been established 
in the Philippines and exerted a rather strict control over all publications. The 1883 liberal Spanish law on printing was not totally implemented in the Philippines, and therefore the censorship was tighter in the archipelago (Cano), so that Valenzuela's statement on satire in the Philippine should be nuanced: most of the satirical weeklies did criticize habits in the Philippines, but before 1898 , the object of satire were social trends-such as the decline of bullfighting and the ascension of horse riding - characters and actions performed by Filipino natives and Chinese, rather than popular Spanish political figures. The most daring criticism might be about some new tax implementation as in the first number of Manililla in January 1893.

The director of La semana elegante, Don Pedro Groizard, was a Spanish journalist who had started his career in Madrid admiring popular satirical caricaturists from the city press such as Galician Luis Taboada (Taylor 22). The flow of directors and owners of newspapers and illustrators from Spain to the Philippines was not strange. Some magazines were transferred from one country to another or were duplicated. Thé kon leche, Miau, El cínife, El Motín, Quiquiriquí, and El Tío Verdades were some of the titles that could be found both in the peninsula and the archipelago. There were also Filipino versions of Spanish magazines: Madrid alegre has a Filipino version published in Manila, Manila alegre; and La ilustración española became La ilustración filipina in the archipelago. The flow of journalists among Spain, the Philippines, and American countries, the roles of cultural mediators, and the connections among periodicals in all those three regions are yet to be studied. However, the similarity of titles did not entail a replica of topics.

The freedom of the press did not arrive in the Philippines at the same time that it did in Spain. The mutiny in 1872 meant a step back in the possibility of softening censorship in Manila (Inarejos Muñoz, "La prensa decimonónica" 205). The law of the press promulgated in 1883 in Spain did have some repercussion in the archipelago (206), although the Reglamento de Asuntos de la Imprenta, managed by the Church remained in force until 1890. Therefore, the increase in the number of newspapers published during 1880s (Cano 172-173) did not mean that the censorship was over. This leads us to two conclusions: (1) the topic of censorship was an ongoing one, and therefore an ongoing problem, and (2) satire in the Philippines would not tackle political issues as other magazines did in peninsular Spain. Rather, it would scrutinize the colonial society.

\section{SATIRE AND RACIALIZATION}

Satire is a classical literary genre that seeks "a reformation of thought" through a fictional representation of reality (Quintero 5). The satirical representation might 
be difficult to discern from truthful representation. The strategy of distortion requires the judgement of the public and relies "on audiences to share a common ground of reason" (5). Ignacio del Villar represents different groups of the Filipino society paying special attention to the representation of matandá or aplatanados: those Spanish individuals who had been in the Philippines for a long time and had adopted habits that differed from those usual in the Peninsula. Despite the appearance of a costumbrista depiction, the intention to highlight the difference of these individuals would have been understandable thanks to the support of those cartoons. Manililla was a magazine addressed to Spanish readers who would share codes with the artist, and therefore would be predisposed to look for humor in the representation of everyday life, finding in satire a confirmation of their social position (Feinberg 206).

The legal and social situation of the Philippines at the end of the nineteenth century was quite complex. Magali M. Carrera attempts in her book, Imagining Identity in New Spain, to apply Homi Bhabha's theory on colonial discourse to the context of New Spain in the nineteenth century. According to Bhabha, colonial discourse was a "complex of signs and practices that organized social existence and social reproduction within colonial relationships" (15). One of the conclusions at which he arrived is that colonialism in the virreinato ${ }^{3}$ challenged the duality between colonizers and colonized. Colonial discourse in both Mexico and the Philippines had to address the epistemological identity of Spaniards, to state who were peninsular, who were kastila, who were criollos, who were non-Spaniards, and what were the characteristics of each group.

Therefore, Kramer's claim of a highly stratified society prevalent in the Philippines must be interrogated by the question itself of who were the peninsulares, who, according to him, occupied the top of the hierarchy:

Spanish colonial society in the islands by the nineteenth century was highly racially stratified, with colonial difference marked in terms of territorial nativity, mestizaje, and religious 'civilización. On the one hand, racial difference was associated with territorial nativity, European nativity - at the pinnacle of colonial society. Philippine 'creoles', or 'Philippine Spaniards', blessed with bilineal Spanish ancestry but corrupted by their colonial births, were beneath them and often resentful of their lesser status. (39)

As Juan Antonio Inarejos discusses in his account of the struggles of a mestizo de sangley to be recognized as a son of a Spanish man because his father was a naturalized Spanish, the difficulty of defining what is Spanish frequently created legal problems (Inarejos, "Nacido en el país"). For this reason, the resolution of his case, published in 1883, included a review of the colonial social stratification (535). A few years before this case, Libro de españoles [Book of Spaniards] and Libro de 
castas [Book of Castes] had been published with the similar purpose of clarifying who was who in the colonies according to their blood input and breed, which were not always clear. Indeed, Fernando Zialcita in "We are all mestizos," proves that mixing between natives, Chinese, and inhabitants of European origin in the Philippines was frequent (Zialcita 223-231), and that not all Spaniards and creoles were on the top of the social scale, in the same way that not all indios were beneath them: segregation was not strictly followed in Manila where, in the nineteenth century, "half of the residents in Intramuros were either indio or mestizo," many of them educated in colleges and seminaries (224). Amidst this confusion, a report by the diplomat Sinibaldo de Mas proposed in 1843 that Filipinos wore a distinctive piece of clothing to distinguish them from Spaniards (Torres-Pou 120). The need for differentiation was not vain, as different racial groups would have different privileges and obligations and, therefore, what was considered a racial distinction would imply a political distinction (Thomas). This was, in fact, the way in which del Villar himself, imitating casta paintings, made his late social taxonomies in a number of drawings, as we appreciate in Figure 2.

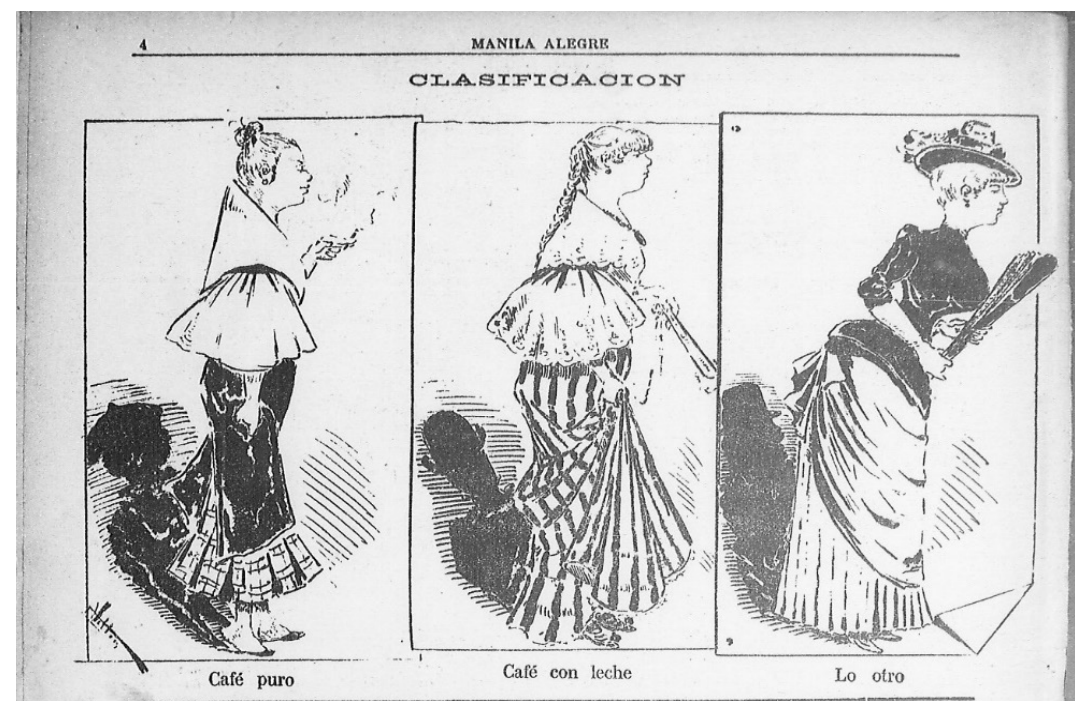

Fig. 2. Del Villar, Ignacio. "Clasificación." Manila Alegre, number 5, 1 February 1886, pp. 4.

The picture titled "Clasificación" [classification] depicts three women: a native Filipina, a mestiza, and a woman dressed in European fashion. The distinction is not in their facial features or skin color, despite the mention of color in the titles under the three feminine figures [pure coffee, white coffee, "the other thing"], but rather in their clothing and hair style. There is a specific kind of man associated 
with each of these women. They appear as a shadow behind the women in the pictures. Each man is distinguished by the kind of hat that he is wearing. Each kind of hat represents a different status of the man. The cartoon mocks the existing obsession with classifying kinds of people and clarifying who is who in the social scale. Such an obsession seems to be related to the need of the Spanish minority to maintain their privileges. The scarcity of peninsular Spaniards in the islands was a real issue often discussed in political circles. It can be seen in the different plans that were brought forward to populate different islands of the archipelago. ${ }^{4}$ Carlos Isabel also highlights this circumstance when talking about the Press in the Philippines in the nineteenth century. In doing so, he quotes figures provided by Ortiz Armengol about the population in 1837, estimated to be composed of three million natives, 200,00o Filipino-Chinese, and 6,00o Spanish [peninsular, creoles, and mixed race with Spanish blood] (Isabel 5).

Going back to the cartoon, satire appears when one would suppose that the last picture of the series would be named "kastila" or "peninsular" but is instead called "lo otro" [the other thing]. The woman of more distinction and "calidad" is not Spanish anymore. There might be two reasons for del Villar joking about this: he considers that Spaniards in the Philippines have been alienated either (1) by the new context, that is, by the nature of the country, or (2) by the lack of other Spaniards and therefore continuous interaction with native peoples. By any of those reasons, he implies that Spaniards in the Philippines cannot be considered the same as those in the Peninsula anymore.

Carrera recalls the notion of calidad, a part of the eighteenth-century legal, social, and visual practices that assessed the qualities of persons of mixed blood (15). Calidad would be a symbolic device of power that was often impossible to see. In this context of blood-mixing and acculturation, in which the colonized looked often exactly as the colonizer in their physical characteristics and behavior, Carrera states that maintaining hierarchy entails shifting the relationship between mimicry and mockery (17).

Previous examples of colonial satire addressed to Europeans "unprepared for the rigors of colonial life" are to be found in American poems in the early nineteenth century (Morris 379). The phenomenon comes endorsed by a rebirth of satire in literary forms in the last decades of the nineteenth century according to Palmeri (Quintero 361). One of the differentiating characteristics of this rebirth of satire is that it criticizes "one side of a cultural opposition, but also turns to undermine the position that its previous criticism had seemed to endorse" (361). In this case, mockery of the Indians would get the attention and participation of the Spanishspeaking public. We must highlight that it was quite a limited public (the community was small) for such a high number of emergent publications. The situation is also 
satirized by del Villar in El Asuang, in which he portrayed the different newspapers of the time (Manililla, La Oceanía Española, El resumen, La voz de Manila, Diario Tagalo) as dogs sharing a few bones with the word "subscription" written on them. The group of "dogs" or newspapers sharing bones is joined by two new dogs, one is El asuang, and the other La broma (Figure 3).

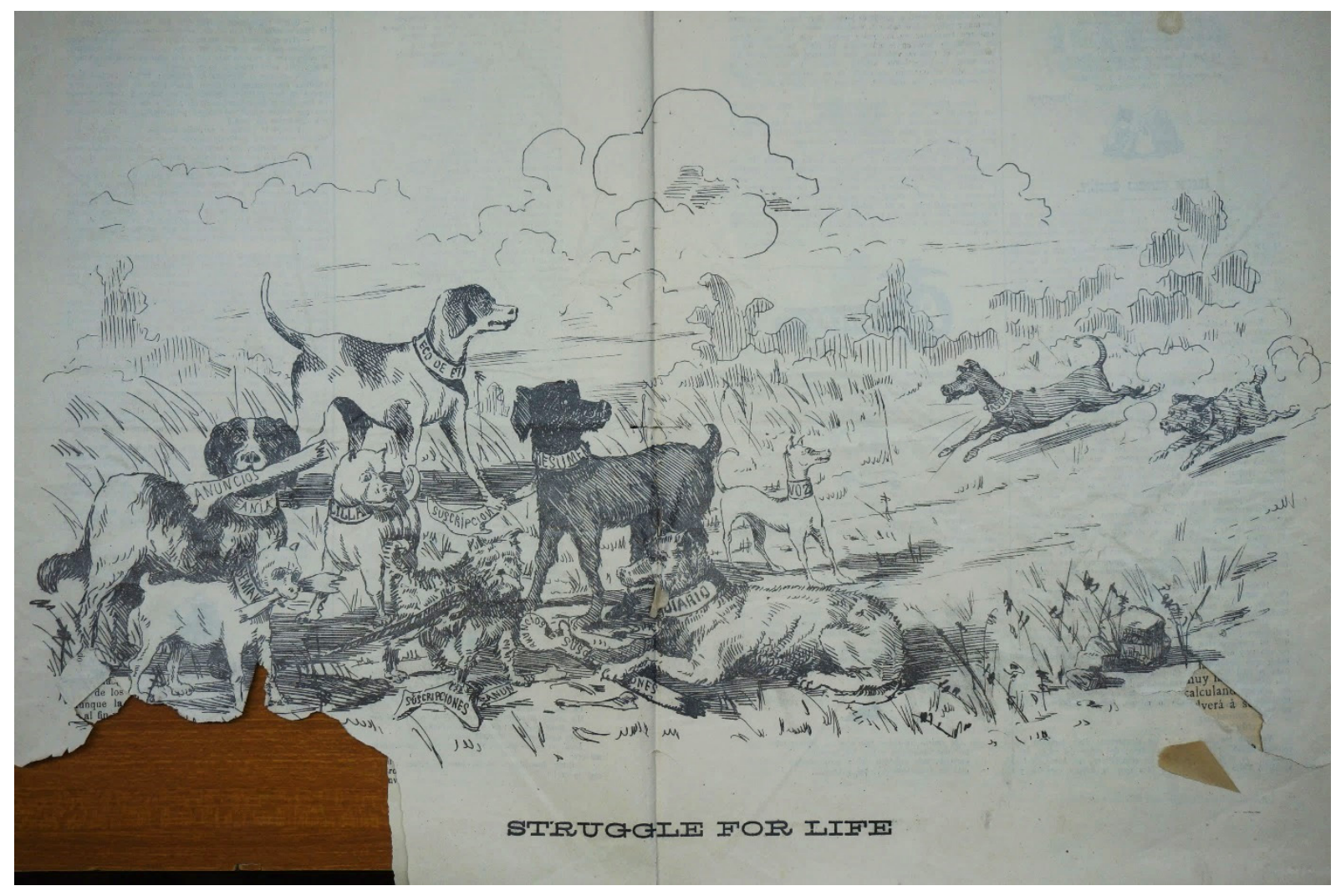

Fig. 3. El Asuang, number VI. 4 February 1892. Library of the Seminary of the Augustinians in Valladolid, Spain.

In this competitive market, the criticism against the native's attitude was the easy bet. However, at the same time, del Villar would introduce an unexpected criticism and questioning of the Spanish-speaking elite's social and moral status. The author positions himself, therefore, not just over the Indians, but also over the Spaniards themselves. This idea sheds some light on why the cartoon by del Villar (Figure 1) showed grotesque depictions of white people and also seemed to mock Indians, who were portrayed as living savagely, climbing trees, and walking naked. 
Ignacio del Villar seems to retake this tradition that Carrera appreciates in Casta Painting of the eighteenth century. Moreover, it mocks Spaniards who have been in the Philippines for too long, as they, in del Villar's representations, "mimic" people living in the Peninsula. The loss of "calidad" in people living for a long time in the Philippines is obvious in their lack of manners, among others, as shown in Figure 4.

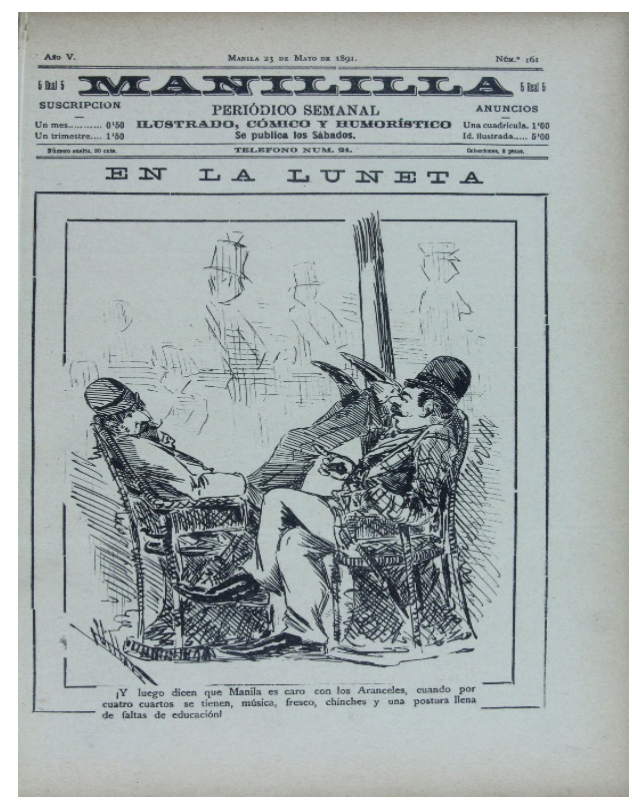

Fig. 4. Del Villar, Ignacio. "En la Luneta." Manililla, number 161, 23 May 1891.

The image shows two Spaniards dressed like the peninsulares, with jackets and bowler hats worn for propriety, although such fashion does not agree with the tropical temperature. In contrast to their attire, they evidence a lack of manners by raising their legs in public, while the caption shows their conversation: ' $\mathrm{Y} Y$ luego dicen que Manila es caro con los aranceles, cuando por cuatro cuartos se tienen, música, fresco, chinches y una postura llena de faltas de educación!' [And so they say that Manila is expensive because of taxes and toll fees. However, for not so much money you may get music, fresh air, and a really impolite posture!]. It must be remembered that the proliferation of books on urbanity in Spain during the nineteenth century had heavily instructed primary school pupils on three main topics: manners, hygiene, and Catholicism (Guereña 62), teaching in detail which body postures were and were not appropriate and relating these rules to social value and abilities $(63,68)$. Those books on manners were widespread in the Spanish colonies, supporting the "civilizing mission" that colonizers were supposed to assume and impose, and that justified their authority. Alda Blanco highlights the 
narrative of progress and civilization that was constructed around the Philippine exhibition of 1887 in Madrid. This narrative allowed peninsular Spaniards to feel their superiority toward the igorrotes exhibited, and at the same time contributed to the imperial narrative of belonging to a nation that had brought "civilization" to "uncivilized" peoples (Blanco 66). Filipinos were regarded as a work-in-progress and such "civilization" brought to them was perceived by the citizens of Madrid in their etiquette and Western attire in cultural events that they attended, and at the closing event of the exhibition (67-68). This already complex situation in Madrid, in which most native Filipinos showed a Westernized attitude by changing their attire, and in some cases rejected that Western identity by refusing to wear European clothing, became even more complex when in the Philippines. Colonizers had left behind the "civilized manners" that expressed their quality and justified their authority, and tended to adopt "savage" attitudes.

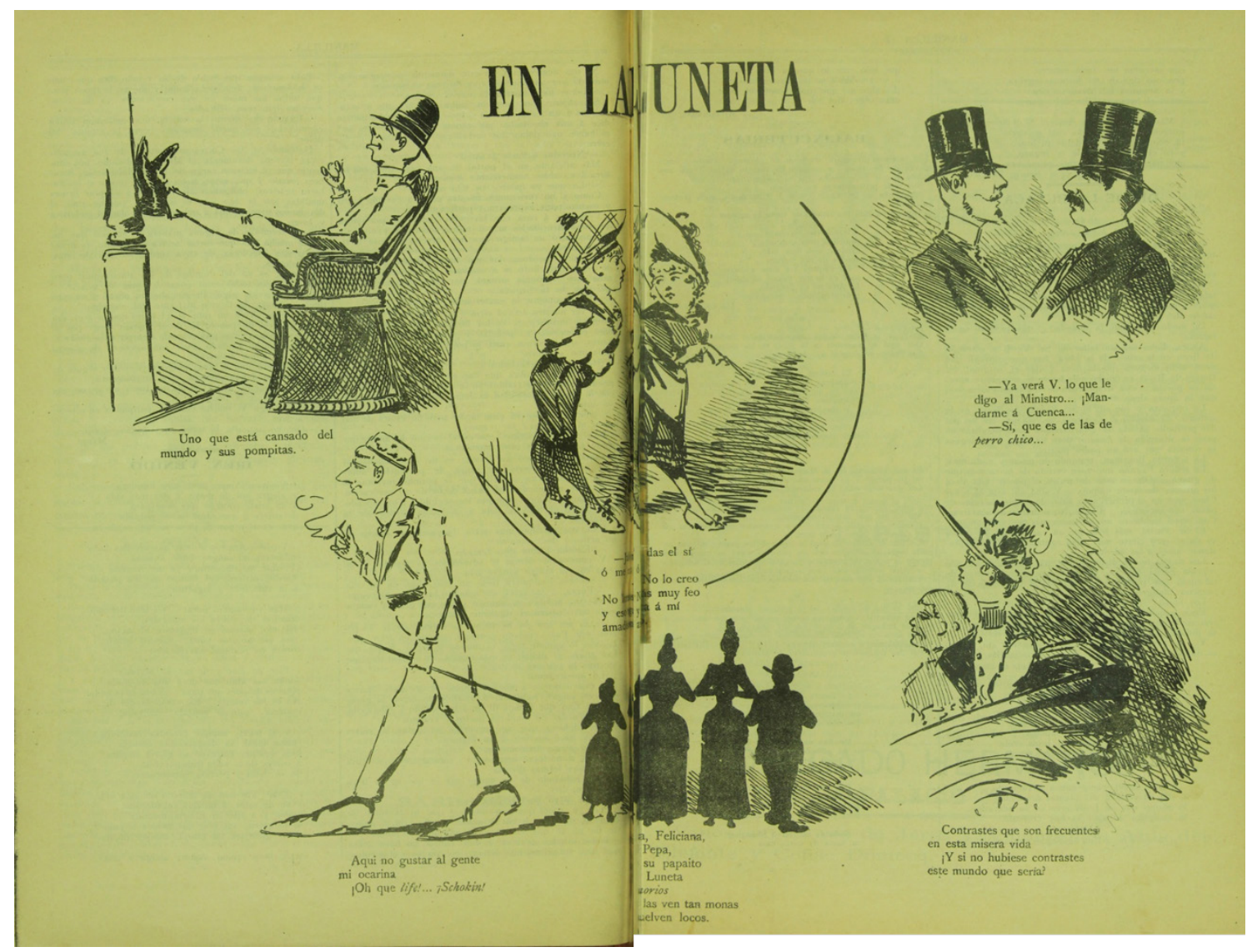

Fig. 5. Del Villar, Ignacio. "En la Luneta." Manililla, number 48, 30 March 1889. 
The displacement and the feeling of estrangement toward the new land incited a familiarity, a "lack of manners" which was supposedly hard to imagine in Madrid. What used to be habitual and acceptable for the kastila self (Spanish-born living in the Philippines, so "the displaced self") was not so acceptable for "the colonial elite self" (that is, citizens of peninsular Spain). The funny representation of two colonizing agents implies their own alienation, claiming a brutalization due to the "uncivilized" environment. There is, therefore, a reversed process in civilization and a hint of its failure, as the colonial context and individuals influence the colonizers, threatening their symbolic authority. The same topic appears again in Figure 5. This is a two-page representation of the kind of people who may be seen walking in Luneta, and they appear as "pretendedly elegant" kastila.

The first illustration on the upper left corner of Figure 5 shows again a man dressed in European attire, lifting his legs while sitting in a public space. The caption "uno que está cansado del mundo y sus pompitas" [someone tired of the world and its pretentions] reinforces the idea that the environment is pushing against manners and their symbolism of dominance. This time, however, the picture is accompanied by other "Tipos" [kinds] that depict different kinds of alienation of Westerners who are away from Europe. Among them, two are to be noted: (1) two kastila who are feeling their lack of importance outside the archipelago as they talk about the provincial city in Spain where one of them (assumedly a public worker) will be destined after his stay in Manila, and (2) a "foreigner" interpreting the role of a "cosmopolitan man," who seems out of place when trying to show his entanglement with folkloric cultures. He finds himself displaced and ridiculed in the urban context of Manila while walking with a Turkish hat and talking about his ocarina, mocking the exotization and orientalization, that is, the homogenization of non-Western cultures. People try to behave there, in Luneta, as if it was not an exotic place but a continuation of the metropolis, rejecting the exoticism that this man searches. There is a question here about whether this exoticism would have been rejected as well in Madrid where, not so long before the publication of this cartoon, the Philippine exhibition in Parque del Retiro had taken place. Luneta, as represented by del Villar, is a grotesque distortion of Madrileño society walking and interacting in Parque del Retiro. This brings out the interesting idea of peninsulares and criollos living in the colony actually imitating the social manners of the Peninsula. The phenomenon of the portrayal of the act and the emphasis on difference is quite similar to what Homi Bhabha calls mimicry. However, in this case, it is applied to Spaniards themselves, rather than to the colonized people. Interestingly, in the representation, mimicry is not just applicable to individuals, but also to space.

In Figure 6, the caption shows a dialogue between a mother and her daughter in which the mother complains because chairs in Luneta seem to have "needles." The 
daughter tries to explain that they are not needles, but bedbugs, however, as she does not seem to remember the word, she describes them as "esos insectos que chupan la sangre humana, feos, repugnantes, que huelen a ... a lo que son" [those insects that suck human blood, and are ugly and disgusting, and stink as what they are]. The mother identifies this description with the Chinese, and then the daughter remembers and clarifies that she meant bedbugs, although she acknowledges that her mother was also right in associating the Chinese with the provided description.

In the picture, Luneta as a social space appears "brutalized" and brutalizing. The specific object of critique is the lack of hygiene in public spaces, concretized by the presence of bedbugs in armchairs, mocking the failure in the attempt to create a distinguished space of social interaction in Manila. This space, in del Villar's representation, becomes exactly that: an attempt. The space is represented as a mimicry of metropolitan spaces, being, as Bhabha would say "almost the same, but not quite." It is by del Villar's representation that the place is othered and shows "its difference."

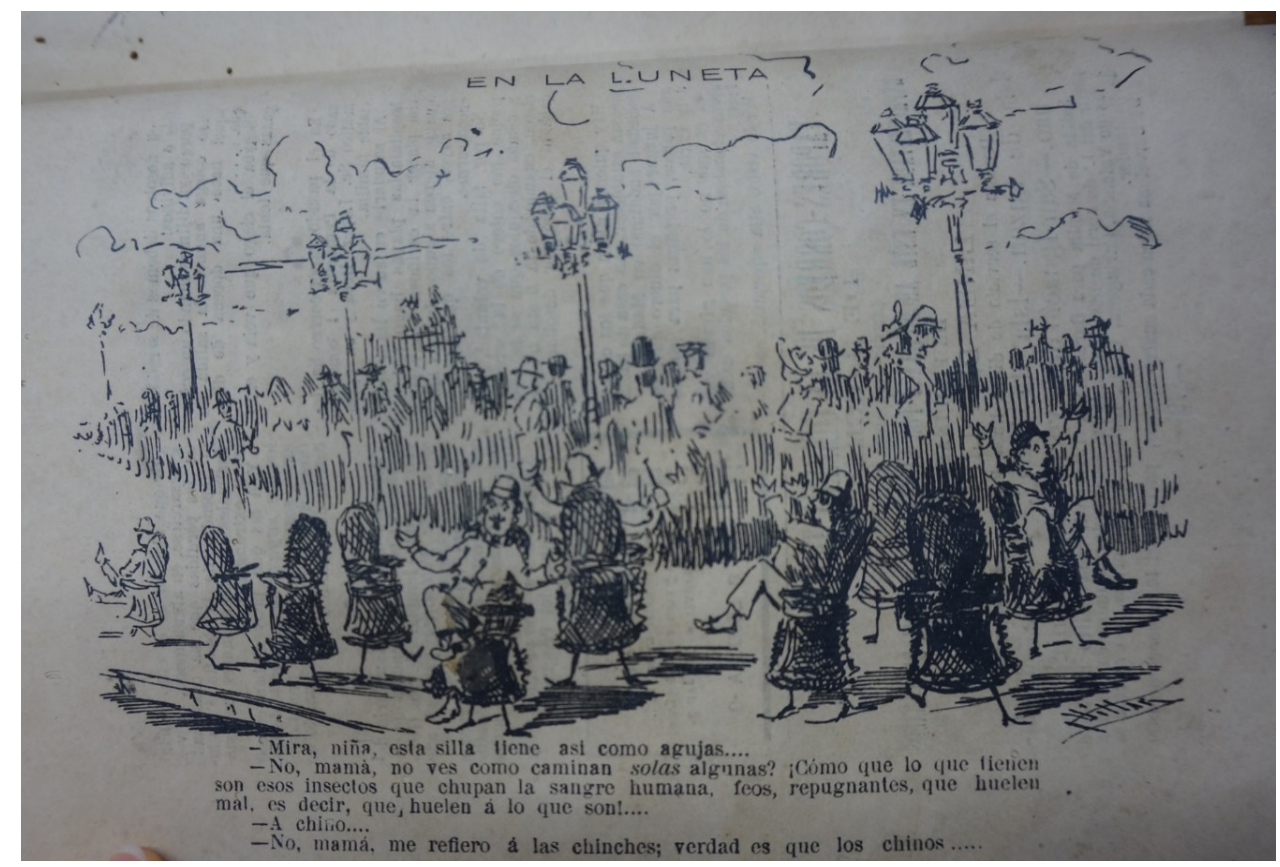

Fig. 6. Del Villar, Ignacio. "En la Luneta." La Pavera, 30 April 1892.

Del Villar partially blamed the environment for the brutalization of people who are, initially, of his own caste. However, going back to Feinberg's theory of satire, by applying satire on them, he demonstrates an attitude of superiority over those 
who by law are superior to him, as they held a higher position in the social scale. He takes enough distance from the civilizing mission and the Spanish colony in the Philippines to see and mock their "de-civilization," so, where does he speak from?

\section{IGNACIO DEL VILLAR}

There are few points in which Wenceslao Retana and Manuel Artigas Cuerva agree with one another in their respective histories of journalism in the Philippines. One is that Ignacio del Villar was one of the main cartoonists at the end of the century. Artigas Cuerva notes in this respect that he is "one of the best we had in the profession" (165).

Ignacio del Villar Ramírez was born in Madrid on 18 April 1860 to Ignacio del Villar y Bustos and Josefa Ramírez Cantero. His father worked as a second class accountant at Hacienda (tax office) in Madrid. When Ignacio del Villar was nine years old, his mother died of typhoid fever. Seven months later his father died of tuberculosis. This is how he became orphaned at a young age. Before dying, his father made a declaration of poverty with a notary, declaring Ignacio del Villar Ramírez as his sole heir. He sent him under the custody of his uncle, Francisco del Villar y Bustos since his grandparents had also died by 1870. This uncle happened to be a journalist and a poet with at least one book published (Renglones desiguales [1885]), as well as a member of the Ateneo in Madrid. Moreover, he held some positions of relative importance in the government; for example, he was appointed head of the correos offices of Cádiz in 1867, and later civil governor of Castellón, Albacete, and Zamora. This brings some ambivalence about Ignacio's social status, as an orphan of a father who had declared himself bankrupt, and as a dependent of an uncle who possessed artistic sensitivity and a prominent socio-economic position. His father, however, had managed to leave him a pension of 250 escudos until his twentieth birthday. With this information, we can say that Ignacio had a comfortable youth in terms if his finances. Similarly, he was raised in a learned environment. ${ }^{5}$

Ignacio del Villar entered the military on 30 April 1880 as seen in the daily Boletin oficial [official bulletin] de Madrid for the said date. ${ }^{6}$ After that, we have mostly bibliographical references on his comings and goings. His name was registered in a list of masons in the Philippines as a guard of the temple of the United Grand Lodge of Manila in 1891 (Cuartero Escobés, La masonería [vol. 1] 105; La masonería [vol. 2] 400). He got married in Manila in 1889 , at the age of twenty seven, to fifteenyear-old Carmen Preysler Montero. According to his living relatives, their first son was born on the ship going back to Madrid in 1895 . 
The first time that del Villar's name appears in the history of Filipino journalism by Artigas Cuerva was in 2 May 1885, when he began to illustrate for Pedro de Groizard and Manuel María Rincón's weekly magazine La puya (160). When the newspaper that specialized in bullfighting failed, both Groizard and del Villar embarked on publishing Manila Alegre, beginning on 4 December 1885. In 1887, when Manila Alegre was included as a weekly supplement to the newspaper La opinión, del Villar separated himself from the project to launch Manililla on his own, a magazine in which he was both illustrator and director (Retana 308-310; Artigas Cuerva 180). According to Valenzuela and Retana, del Villar traveled to Hong Kong and China a few months after Manililla started to be published. The magazine stopped and then returned once he came back to the Philippines, adding poems by José García since then (Valenzuela 56; Retana 310). One year later, Manuel María Rincón became responsible for editing the magazine and in 1892, he bought it from del Villar, who would be returning to Spain (Valenzuela 56). Manuel M. Rincón relaunched the magazine with some success, becoming one of the longerlasting magazines at the time. He published illustrations from del Villar and others until 1896, when Rincón returned to Spain.

In 1890, del Villar was also an illustrator in Manila for El caneco and Un pájaro verde, and at least from 4. February to 19 May, he drew for El Asuang two caricatures for every issue: one using his own name on the cover, and one under his pen name pen name "Quin-qué" in the caricatures on the inside pages.

Retana affirms that del Villar returned to Spain in May 1892 (312). In fact, his arrival in Madrid was announced in the 16 July 1892 issue of the newspaper La correspondencia de España, where they dedicate a brief note to him: "Ha llegado a esta corte el distinguido dibujante D. Ignacio del Villar, director artístico que ha sido de varios periódicos en Manila, de cuya capital regresa" [The distinguished cartoonist Ignacio del Villar has arrived in this court. He has been the artistic director of different periodicals in Manila, from which he is coming back]. Interestingly, and despite the epithet "distinguished" that accompanies his name, he did not do much in Madrid during his time there. I could only track a note in the Madrid newspaper La unión católica on 2 January 1893, announcing that he would soon start up a Spanish newspaper in Spain called La Ilustración hispanofilipina, collaborating with the Cantabrian Ventura Fernández López. If the project did launch, it must not have lasted, because in June 1893, del Villar was in Manila again, illustrating for El diablillo suelto (15 June 1893). It is likely that between 1893 and 1895 , del Villar went briefly to Spain, as Retana in his book in 1895 confirms that he had just returned to Manila after learning the art of photoengraving in Madrid (619). After this supposed trip, Artigas Cuerva affirms that del Villar was in the Philippines until a little while after the revolution broke out, so he must 
have returned to Spain in 1896, when Manuel M. Rincón also left, thereby closing Manililla.

We know that during his stay in Madrid he worked for the newspaper La nación militar. His illustrations appeared in issues between April 1899 and February 1901. However, we do not see him in the greater satirical newspapers that were published at the time, unlike another illustrator who was in the Philippines until the revolution and soon made a name in the small world of Spanish caricature: Vicente Tur, a name that is obligatorily referenced in studies on the origins of the Spanish comic strip, in which del Villar barely appears.

This failure in the Spanish scene brings to the surface some reflections regarding some of his drawings, which depict the pretentious attitude of Spaniards in the Philippines. As we started to see, there is an insistence on the unmasking of the attitudes of those who seem to have great importance in the colony in contrast with their lower social status in the peninsula, which is perceived as the "reality" (Figure 7).

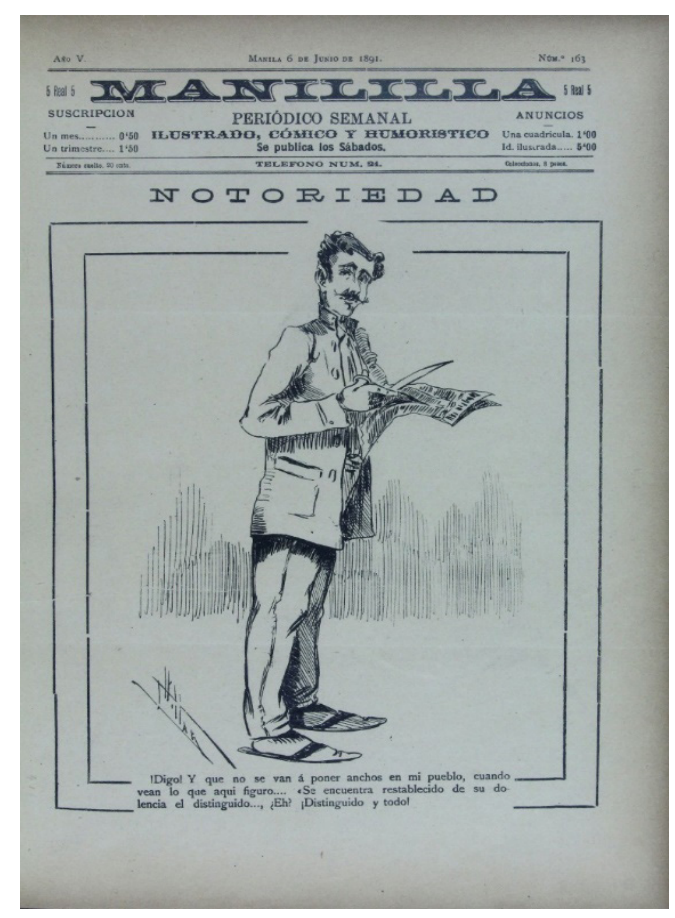

Fig. 7. Del Villar, Ignacio. "Notoriedad." Manililla, number 163, 6 June 1891. 
In Figure 7, we have exactly this: a gentleman wearing a military-like suit and chinelas (slippers), saying “ ¿Digo! Y que no se van a poner anchos en mi pueblo cuando vean lo que aquí figuro... 'Se encuentra restablecido de su dolencia el distinguido... ¿eh? ¡Distinguido y todo!'” [Oh well, people in my village are going to feel really proud as they see how important I am here... 'Distinguished Mr... has totally recovered from his sickness']. It captures a Spanish resident in the Philippines in a supposed state of self-awareness. Implying that Spaniards usually take for granted their high status and success in the Philippines, del Villar shows how random and false this situation is, if compared to the reality in the Peninsula. The picture brings us back to the notion of "calidad" applicable to the colonial context. There, Spaniards would assume that they deserved a high position in the social hierarchy just for their origin. Interestingly, we again see in the cartoon the epithet "distinguished" that had been applied to Ignacio del Villar himself in La correspondencia de España when he arrived in Madrid in 1892. On portraying the deviation in the habits of the kastila (a Spaniard who has lived in the Philippines for a while), del Villar brings up a certain kind of trauma caused by the discord between the kastila's self-perception, their reality, and their presence in the public sphere. In a newer version of "unhomeliness" described by Homi Bhabha, the strange, outside world determines the private sphere, in which context contradicts the identity that the colonizer believes to have ("The World and the Home" 141).

Del Villar's detachment from this attitude through satire seems to have been provoked by his awareness of his situation: although he was considered an unmissable illustrator in the archipelago according to Retana and Artigas Cuerva, he was totally ignored in Madrid. This experience provides him with a lucid view over the social game of appearances kept by peninsulares in the Philippines that he captured in his cartoons. In them, fake efforts are shown on the part of the elite to differentiate themselves in the complex social structure already described. Such is also the case in Figure 8. On the cover of the 19 December 1891 issue of Manililla appears a caricature called "Después del baile," in which a dark-skinned Filipina enters a pawnshop with a package. The caption is the conversation in the caricature: "Pero mujer, ¿otra vez por aquí a empeñar la ropa que sacaste hace tres días? ¡Abá! Pude sacar no ms para el señorita que nesesitá llevarlo en el baile” [Hey woman, how come you are back here to pawn the clothes you recovered three days ago? / ¡Abá! I could just barely take them out for the señorita to wear them for the ball].

The comings and goings from the pawnshop speak of poverty being hidden for the sake of the kastila mistress, as well as a certain need for a rich and showy appearance. Clothes would indeed become a mechanism for justifying a status that was otherwise difficult to establish in Manila society, as was seen in Figure 2 and as was mentioned in the discussion about castes and calidad in Manila society. In 


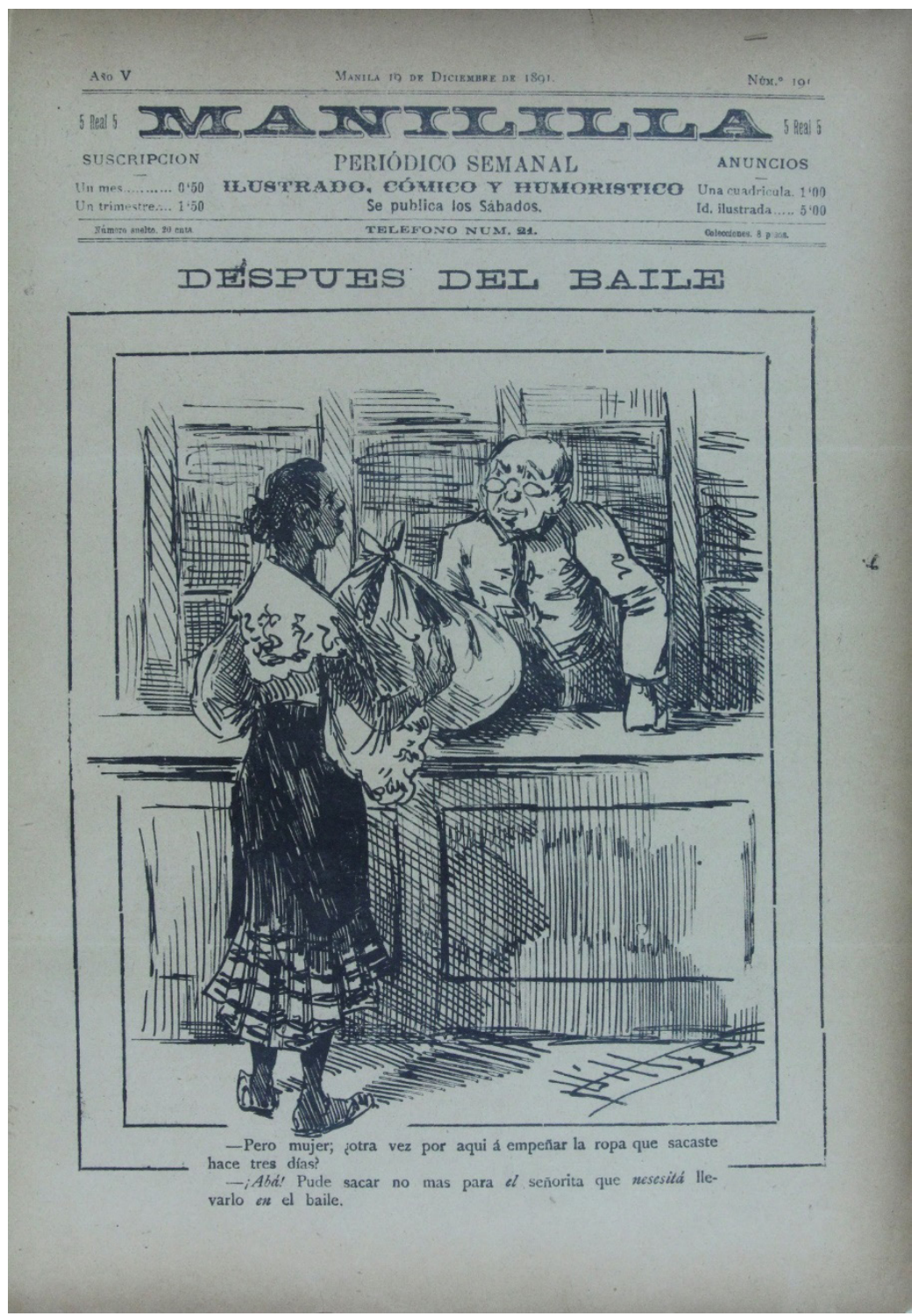

Fig. 8. Del Villar, Ignacio. "Después del baile." Manililla, number 21. 19 December 1891.

this cartoon, apart from mocking peninsular Spanish attitudes, del Villar used a mechanism of superiority by highlighting errors in the use of the Spanish language by the Filipino people (Feinberg 215). However, the self-awareness developed seemed to bring him out from the "monarch of all I survey" topic, and made him an intruder in the colonizer's world, as what happened to women in the satiric accounts described by Pratt. 
The idea of being out of place in the peninsulares' fake and exclusive bubble seemed to be supported by his activities in the Philippines. Cristina LaconicoBuenaventura discusses in her article on theaters in the Philippines the highly stratified cultural life in the country in the kinds of "teatros" existing at the end of the nineteenth century. In the section on "teatro tagalo," in which she discusses the places for staging popular plays in the vernacular language, she mentions teatro guiñol (puppet theater), owned and run by Ignacio del Villar himself (LaconicoBuenaventura 31). Apparently, in 1896, del Villar requested to move Teatro guiñol to Bagumbayan (an old name for La Luneta Park). The governor seemed to have accepted the petition "on condition that the theater be decorated and made presentable, since Bagumbayan was much frequented by those who came to enjoy the cool breeze of adjoining Manila Bay" (32). If we trust the cartoons seen portraying the lack of real "calidad" of people in La Luneta and mocking their elegance, we might suggest that investing in the appearance of the theater for pretentiously elegant people to come to the functions was not a decision that he loved. The fact that he owned a Tagalog theater venue implies that he mingled with Tagalog-speaking people.

Perhaps due to the little success that he had in Spain, del Villar returned to the Philippines in 1901, when we find again his cartoons in the magazine Biro-biro, in which he began to illustrate about more political themes criticizing American imperialism. The last tracks that we have of del Villar date back between the years 1905-1909. At least since 14. October 1905, he was in Madrid collaborating with Monos, where the abovementioned Vicente Tur frequently published. Finally, Artigas Cuerva confirmed in his book of 1909 that del Villar still lived in Spain (165). However, his relatives affirm that he died of bleeding in the stomach on a ship returning to Barcelona in 1906. He had three children.

\section{REPRESENTATION OF INDIOS}

Del Villar managed to distance himself from the Spanish society as portrayed in his cartoons because he was a matandá/aplatanado at some degree. However, despite his adaptation to the Philippine environment, he still represented Filipino natives in a colonial fashion. Although they were not the main target of his satire, they were still considered a constituent part of the environment that produced the estrangement on peninsulares. Perhaps this was how he achieved success in the Philippines: his audience, often those kastila that he would often criticize, shared his view in the sense that they understood the surprise that Filipino objects, Filipino landscape and natural phenomena, and Filipino habits produced. By empathizing with this surprise, humor is produced. As a maker of the "[c]ritical 
distortion of the familiar" that is satire (Feinberg 19), the satirist should have an idea of a reasonable reality shared with his audience and a consciousness of the difference and superiority toward what is critiqued (Quintero 5), comparable to Mary Kingsley's accounts of her Travels in West Africa as described by Pratt (209).

Homi Bhabha maintained that while the native was enslaved in the colonial society for his inferiority, the white man was enslaved by his superiority in the eyes of the Other and of his kind. The enslavement was produced by a set of rules of conduct and expectations of behavior that obliged and bound the colonizers to perform a given role and fulfil the natives' expectations. Bhabha expressed this reciprocal enslavement in a tragic manner as determining the racism of the Other:

The representative figure of such a perversion, I want to suggest, is the image of postEnlightenment man tethered to, not confronted by, his dark reflection, the shadow of colonized man, that splits his presence, distorts his outline, breaches his boundaries, repeats his action at a distance, disturbs and divides the very time of his being. This ambivalent identification of the racist world-moving on two planes without being in the least embarrassed by it, as Sartre says of the anti-Semitic consciousness-turns on the idea of Man as his alienated image, not Self and Other but the 'Otherness' of the Self inscribed in the perverse palimpsest of colonial identity. (The Location of Culture 62).

Del Villar's drawings, including Figure 8, expressed openly and questioned this enslavement of the white man, subverting the logic of the system by exposing it. However, in order to maintain the colonial right over the natives, del Villar stereotyped the Filipinos as an integrative part of the nature, marking them "as wild and barbaric" as foreseen by Bhabha. The very word indios uniforms native peoples from India and from all the Spanish colonies in Asia and the Americas. It is a form of unifying all that is not Western and justifying the use of power and the necessity of colonization (Bhabha, The Location of Culture 61-70 and 95-96). This is to say that the representation of the colonized is simplified according to certain stereotypes that justify the unifying presence of the colonizer. Various critiques agree, although with nuances, when it comes to this point of view. Edward Said's analysis of this is probably the best known: it talks about how the "East" is made uniform by the gaze of the "West," who constructs an image of the unknown, of the Other, exotic, and uniform. Meanwhile, Franz Fanon questions the identity of the colonized, the alienation to which colonization submits it, to the point of imitating structures and becoming accustomed to Western racism and classism. Bhabha historicizes these and frames postcolonial discourse within power struggles, identity inculcation, and the production of knowledge about the colonized and colonizer evaluated stereotypically (The Location of Culture 94-95). The former is applicable to the caricatures of the period, not only del Villar's, in which a racist and derogatory idea of the Filipino indio appeared. ${ }^{7}$ 
On the other hand, in the illustration from 23 March 1889, we see the custom of "mata-mata," consisting of "limpiar uno la cabeza á otro, sin más elementos que los dedos de las manos" [cleaning each other's heads just with their fingers] (Chápuli Navarro 317). Indios are animalized by being represented with apish faces or as a bunch of monkeys deworming each other. The mechanism of dehumanizing the Other is seen as part of the ideological process of racialization (Figure 8).

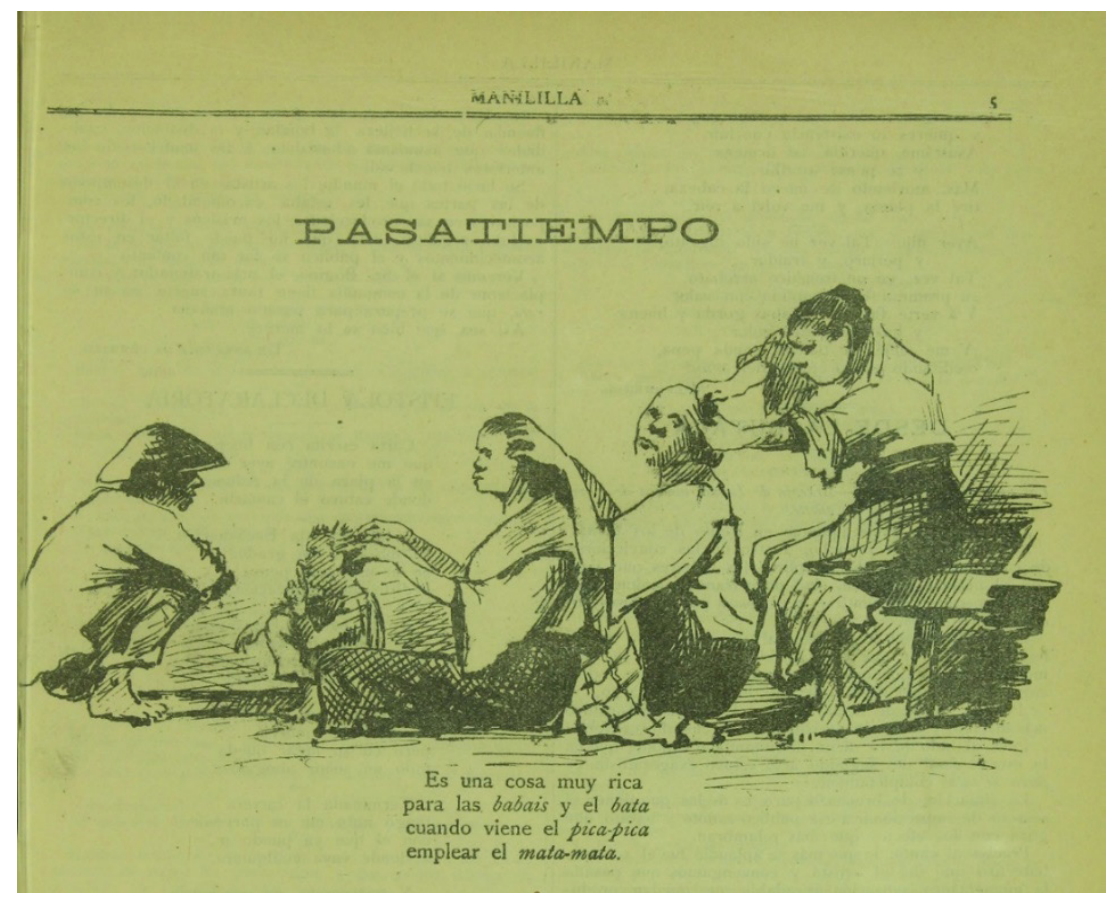

Fig. 9. Del Villar, Ignacio. "Pasatiempo." Manililla, number 47, 23 March 1889, pp. 5.

The caricature represents a preconception of the Other: its savagery. The perspective of the Spaniard is represented, said to be mediated by preexisting structures. Animalization is a trope that also allows colonial discourse by justifying the prevailing power structure in a system at the closing of the nineteenth century. The mechanism highlights a mentality which was proven to be institutionalized by the exhibition on the Philippine Islands organized in Madrid in 1887. This ethnological exhibition, which was said to be organized for the Spaniards to learn from the most remote of their colonies and create feelings of brotherhood between both peoples (Sánchez Avendaño 271), had samples of the flora, fauna, and peoples from the Philippine Islands living in El Retiro Park in Madrid. Furthermore, "mostraba una visión de lo colonial impregnada de la idea de superioridad europea, la utilidad económica y comercial de esos espacios, los beneficios civilizadores de 
los colonizadores . . . conceptos todos ellos muy presentes cuando nos movemos en el colonialismo europeo, pero que tienden a olvidarse en relación con España" [(it) showed a colonial vision impregnated with the European idea of economic and commercial superiority, and the idea of utility of spaces, the civilizing benefits of colonizers... all of them concepts really present when we are talking about European Colonialism. However, they tend to be forgotten in relation to Spain] (Calzada del Amo 161). The exhibition was noticed and criticized by José Rizal, who considered that their compatriots were being degraded by it (Rizal qtd. in Sánchez Gómez 251).

Moreover, customs which are related to Spanish traditions through the Catholic religion were parodied when indios performed them. On the cover of the 21 February 1891 issue of Manililla (Figure 9), a reference is made to the singing of the

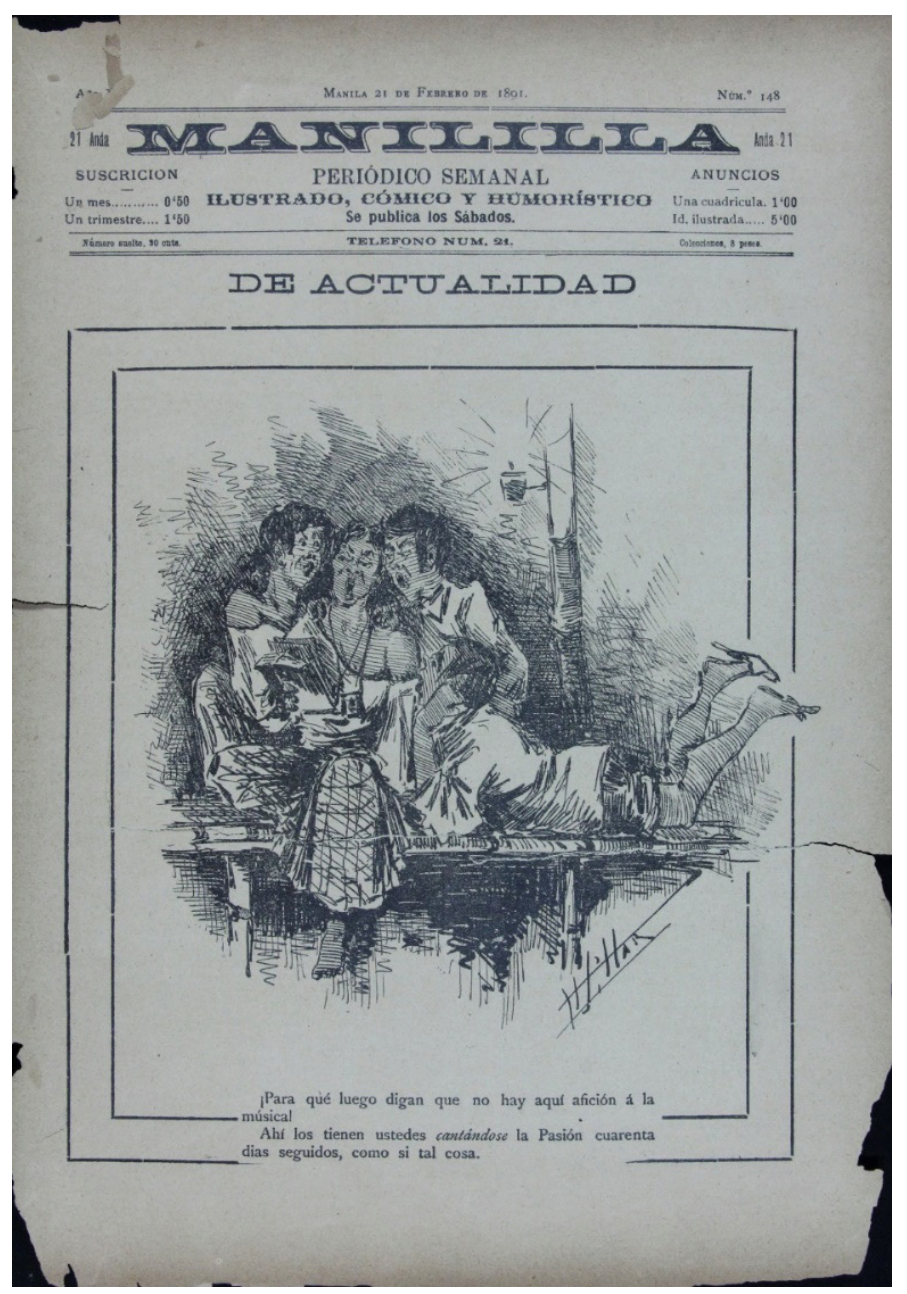

Fig. 10. Del Villar, Ignacio. "De actualidad." Manililla, number 148, 21 February 1891. 
pasyon, the Filipino tradition of Pabása ng pasyón which is practiced up to this day in some places.

It is done during Lent, when some families and religious congregations would do a sung reading of passages from the Passion of Christ for many consecutive days without stopping, even during the whole Lenten season (taking turns among themselves) as the caption seems to indicate: "Para que luego digan que no hay aquí afición a la música. Ahí los tienen ustedes cantándose la pasión cuarenta días seguidos como si tal cosa" [and then you complain about the lack of liking for music here. There you can see them singing 'la pasiyon' for 40 days on a row like it were nothing] (Figure 9). The custom, despite the Christian content, adopts the form and aesthetics of epic narratives and native Philippine theater (Bräunlein 92) in which local epics were also sung for consecutive days. This gave way to the present-day tradition of singing the pasyon. The devotion to the faith throughout the chanting, though considered to be archaic and partly of Spanish origin, calls the attention of the nineteenth-century Spaniard. Catholicism left some of its roots in the country and adopted native forms which are no longer recognized as the colonizer's own. Upon seeing other versions, the Spaniard refers to them condescendingly.

These forms of representation under the disguise of satire, have the purpose of widening the breach between what Bhabha calls "post-Enlightened man" and its "dark shadow." The colonizer, aware of their brutalization, generates solidarity and brotherhood, and tries to strengthen their identity ties with the metropolis by ridiculing the Other and showing their condescendence toward anything which breaks the kastila code of good manners. Del Villar manages to get the kastila to laugh at themselves and also to justify their deviations from the Western code. Furthermore, the kastila adduces the influence of the environment and reaffirms their identity by confirming their superiority over the subaltern.

\section{CONCLUSION}

Ignacio del Villar's place, resisting aplatanado attitude but also keeping distance from the criticism exercised by Spanish recently arrived in the Philippines from the peninsula, provide him with a privileged view from an in-between position to portray colonial society in the Philippines. His role subverts the traditional view of the colonizer as described by Pratt, partly because her analysis of colonial texts does not include the integrative model that some Spaniards adopted in the Philippines and in Latin America. Del Villar mocks the top of the hierarchy in Philippine society, that is, Spanish Peninsulares, in their ambition to imitate Madrid society. However, he does not identify with native peoples either, who are 
portrayed in his cartoons as animalized, following colonial depictions at the time. Therefore, we find in his pictures a subversive reaction against appearances related to his experiences of success in the Philippines and failures in Madrid. Moreover, we find a typical colonial attitude toward native Philippines, despite his higher degree of mélange with them, thanks to the puppet theater that he owned. His outsider view and unstable position between Spain and the Philippines enable him to paint pictures that offer an excellent portrayal of Philippine society during the waning years of the Spanish colony. However, after his return to the Philippines in 1901, his cartoons became more political. This proved to be a manifestation of his disappointment with the American government in the Philippines, and the increase of press freedom brought by the end of the Spanish occupation. 


\section{Notes}

1. Information was obtained from the Phivolcs official website, http://www.phivolcs. dost.gov.ph, accessed on 21 September 2015.

2. "Aplatanado" was a popular word used in the Spanish colony in the Caribbean islands to define Spanish individuals who, after a long time living there, had adopted local habits. Fernando Ortiz defines aplatanados in Cuba as "ciudadanos o no, que, nacidos allende los mares, han crecido y formado sus personalidades aquí, en el pueblo cubano, se han integrado en su masa y son indistinguibles de los nativos; son ya cubanos o como cubanos, más cubanos que otros que sólo son tales por su cuna" (Ortiz, Fernando Ortiz y la cubanidad 5). ["Cubans, citizens or no, who, born across the seas, have grown and formed their personalities here, among the Cuban people. They have integrated themselves into its mass and are indistinguishable from the natives. Already they are Cubans or like Cubans, more Cuban than others who have the name only because of their cradles or their documents." (Ortiz, "The Human Factors of Cubanidad")]. The adaptation in the Philippines is sometimes "matandá" meaning "old man" in Tagalog, as seen in José Montero y Vidal's short story "El vago y el matandá" (the newbie and the old man) (Montero y Vidal 85).

3. She focuses on Mexico, although the Philippines was also New Spain.

4. From the second half of the nineteenth century, different proposals have been made and kept in historical archives. In 1854, there was a proposal to bring surgeons to villages in the Philippines in order to increase the population and, therefore, the agricultural production. In 1890 , there was a proposal to create a council to encourage emigration to the Philippines. In 1891, the plans to colonize parts of the archipelago with fewer Spaniards started. There was as well a plan in 1895 to populate Mindanao and other points of the Philippines with Spanish emigrated from Algeria and Argentina. They are all a consequence of the low number of Spanish residing there and the prevalence of "Indians" and Muslims (especially in Mindanao).

5. The information about his early life has been provided by Herica Hanson, who is married to one of Ignacio del Villar's great grandchildren. His family has been inquiring different administrations about their relative's life and they have shared with me the information that they have obtained from the Spanish National Archive with me very generously.

6. This information was also generously provided by Herica Hanson.

7. An example of this besides del Villar's caricatures appeared in issue 18 of the magazine El tío Paco, published in Manila on 6 July 1902, where native peoples from Mindanao were represented as violent savages cutting off heads of Western people with swords. In the same magazine on 9 March 1902, a Philippine indio appears servile, pulling a cart for the transportation of white people.

Kritika Kultura 33/34 (2019/2020): 32-035

(C) Ateneo de Manila University

<http://journals.ateneo.edu/ojs/kk/> 


\section{Works Cited}

Artigas Cuerva, Manuel. Los periódicos filipinos. La más completa bibliografía publicada hasta la fecha acerca de los papeles públicos filipinos. Biblioteca Nacional Filipina, 1909.

Bhabha, Homi. The Location of Culture. Routledge, 2004.

--. "The World and the Home." Social Text, vol. 31-32, 1992, pp. 141-153.

Blanco, Alda. Cultura y conciencia imperial en la España del siglo XIX. Universitat de València, 2015.

Borrero, Francisco. Cuestiones filipinas. Viuda Minuesa de los Ríos, 1896.

Bräunlein, Peter J.. "Who Defines 'the Popular'? Post-colonial Discourses on National Identity and Popular Christianity in the Philippines." Religion, Tradition and the Popular: Transcultural Visions from Asia and Europe, edited by J. Schlehe and Evamaria Sandkühler, Transcript Verlag, 2014, pp. 75-114.

Calzada del Amo, Esther. Germán Gamazo 1840-1901: poder político y redes sociales en la Restauración. Marcial Pons, 2011.

Cano, Gloria. "Filipino Press between Two Empires: El Renacimiento, a Newspaper with Too Much Alma Filipina." Southeast Asian Studies, vol. 49, no. 3, 2011, pp. 395-430.

Carrera, Magali M. Imagining Identity in New Spain: Race, Lineage, and the Colonial Body in Portraiture and Casta Paintings. U of Texas P, 2003.

Chápuli Navarro, Antonio. Siluetas y matices. Galería filipina. Madrid: La viuda de M. Minuesa de los Ríos, 1894.

Cuartero Escobés, Susana. La masonería española en Filipinas (vol. 1). Ediciones IDEA, 2006.

-.. La masonería española en Filipinas (vol. 2). Ediciones IDEA, 2007.

De Llobet, Ruth. "El poeta, el regidor y la amante. Manila y la emergencia de una identidad filipina criolla." Istor, vol. 38, 2009, pp. 65-92.

Fanon, Franz. Black Skin, White Masks. Grove Press, 1967.

Feced, Pablo. Filipinas: esbozos y pinceladas. Establecimiento topográfico, 1888.

Feinberg, Leonard. Introduction to Satire. Iowa State UP, 1967.

Fulgosio, Fernando. Crónica de las Islas Filipinas. Rubio, Grilo y Vitturi, 1871.

González Serrano, Valentín. España en Filipinas. R. Velasco, 1896.

Guereña, Jean-Louis. "Urbanidad, higiene e higienismo." Areas. Revista Internacional de Ciencias Sociales, vol. 20, 2000, pp. 61-72.

Guilarranz Ibáñez, Ainoha. "La representación gráfica de España en la publicación republicana La Flaca." El argonauta español, vol. 9, 2012. http://journals.openedition. org/argonauta/1540. Accessed 14 Jan. 2019.

García Castañeda, Salvador (coord.) La fuerza del humor: revistas satíricas del siglo XIX. (catalogue of the exhibition). University of Cantabria. Fundación Joaquín Díaz, 2013. http://www.funjdiaz.net/imagenes/catalogos/catalogo_satiricas.pdf. Accessed 14 Jan. 2018. 
Halili, Servando. D. "Media Play: The Filipino through the Eyes of the Imperialist's Caricature." Iconography of the New Empire. Race and Gender Images and the American Colonization of the Philippines, edited by S. D. Halili, U of the Philippines P, 2006, pp. 36-8o.

Ignacio, Abe. et al. The Forbidden Book: The Philippine-American War in Political Cartoons. T'Boli Publishing, 2004.

Inarejos Muñoz, Juan Antonio. "La prensa decimonónica en Filipinas. De la censura al soporte revolucionario." Redes de comunicación: Estudios sobre la prensa en el mundo hispanohablante, edited by Yvette Bürki and Henriette Partzsch, Frank \& Timme GmbH, 2016, 199-212.

--. 'Nacido en el país al amparo de la hidalga nación española': los usos del factor racial en el control del poder local en Filipinas a finales del siglo XIX." Revista de Indias, vol. 75, no, 264, 2015, pp. 529-554. http://revistadeindias.revistas.csic.es/index.php/ revistadeindias/article/view/995/1067. Accessed 14 Jan. 2019.

Isabel, Carlos. "Nacimiento y evolución de la prensa en Filipinas en el siglo XIX: de los intereses españoles al nacionalismo filipino." Revista Internacional de Historia de la Comunicación, vol. 8, 2017, pp. 1-24. http://institucionales.us.es/revistarihc/ documentos/rihc-08-articulo-01-prensa-filipinas-siglo-xix.pdf. Accessed 14 Jan. 2019.

Kramer, Paul. The Blood of the Government: Race, Empire, the United States and the Philippines. Ateneo de Manila UP, 2006.

Laconico-Buenaventura, Cristina. "Theaters of Manila 1846-1896." Philippine Studies, vol. 27, no. 1. 1979, pp. 5-37. http://www.ojs.philippinestudies.net/index.php/ps/article/ viewFile/4032/6037. Accessed 14 Jan. 2019.

Lent, John. "Cartooning in Southeast Asia." Encyclopedia of Humor Studies, edited by Salvatore Attardo, Sage, 2014, pp. 724-727.

--. "Comic Art in the Philippines." Philippine Studies, vol. 46, no. 2, 1998, pp. 236-248.

López Ruiz, José María. La vida alegre: historia de las revistas humorísticas, festivas y satíricas publicadas en la Villa y Corte de Madrid. Compañía literaria, 1995.

Marimon Riutort, Antoni. "Entre el humor y la política. La prensa satírica durante la Restauración: el caso de Mallorca. Pasado y Memoria." Revista de Historia Contemporánea, vol. 16, 2017, pp. 149-175. https://doi.org/10.14198/PASADO2017.16.o7. Accessed 14 Jan. 2019.

Montero y Vidal, José. "El vago y el matandá," Cuentos Filipinos. Tip. del Asilo de huérfanos del Sagrado Corazon de Jesús, 1883.

Morris, Linda A. "American Satire: Beginnings through Mark Twain." A Companion to Satire, edited by Rubén Quintero, Blackwell, 2007, pp. 377-399.

Muñoz Vidal, Agustín. "Filipinas en la ilustración gráfica de la segunda mitad del siglo XIX en España." Revista española del Pacífico, vol. 8, 1998, pp. 289-304.

Ortiz, Fernando. Fernando Ortiz y la cubanidad. Fundación Fernando Ortiz, 1996.

--. "The Human Factors of Cubanidad." Translated by J. F. Gonçalves and G. D. Morton. HAU: Journal of Ethnographic Theory, vol. 4, 2014, pp. 445-48o.

Philippine Institute of Volcanology and Seismology [PHIVOLCS]. https://www.phivolcs.dost. gov.ph/. Accessed on 21 Sept. 2015. 
Pratt, Mary Louise. Imperial Eyes: Travel Writing and Transculturation. Second edition. Routledge, 2008.

Quintero, Rubén. A Companion to Satire. Blackwell Publishing, 2007.

Retana, Wenceslao E. El periodismo Filipino: noticias para su historia (1811-1894). Minuesa de los Ríos, 1895.

Said, Edward. Orientalism. Penguin, 1978.

Sánchez Avendaño, María Teresa "Análisis histórico y sociológico de la Exposición de Filipinas en la España finisecular." Revista española del Pacífico, vol. 8, 1998, pp. 271-287.

Sánchez Gómez, Luis Ángel. Un imperio en la vitrina: el colonialismo español en el Pacífico y la exposición de Filipinas de 1887. CSIC, 2003.

Sierra de la Calle, Blas. Hazañas Yankees. Diseños satíricos de 1898. Museo oriental, 1998.

Spurr, David. The Rhetoric of Empire: Colonial Discourse in Journalism, Travel Writing, and Imperial Administration. Duke UP, 1993.

Taylor, Carson. History of the Philippine Press. Manila, n.pub., 1927.

Thomas, Megan. Orientalists, Propagandists and Ilustrados. Kindle version. U of Minnesota P, 2012.

Torres-Pou, Joan. Asia en la España del Siglo XIX: Literatos, viajeros, intelectuales y diplomáticos ante Oriente. Rodopi, 2013.

Valenzuela, Jesús Z. History of Journalism in the Philippine Islands. J. P. Cruz, 1933.

Velasco Shaw, Ángel. Vestiges of the War. The Philippine American War and the Aftermath of an Imperial Dream. New York UP, 2002.

Vila, Francisco. Filipinas. Viuda e hijos de J. A. García, 1880.

Zialcita, Fernando N. Authentic though not Exotic: Essays on Filipino Identity. Ateneo de Manila UP, 2005. 